Hageman, S.J., James, N.P. and Bone, Y. 2000. Cool-water carbonate production from epizoic bryozoans on ephemeral substrates. Palaios, 15(1) : pp. 33-48. Feb. 2000. Published by Society for Sedimentary Geology (SEPM) (ISSN: 0883-1351) The version of record is available at http://palaios.geoscienceworld.org/ [Archived with permission of the editor received Feb 22, 2011]

\title{
Cool-Water Carbonate Production from Epizoic Bryozoans on Ephemeral Substrates
}

\author{
Steven J. Hageman, Noel P. James, \& Yvonne Bone
}

\begin{abstract}
Bryozoan skeletons are a dominant constituent of cool-water carbonate sediments in the Cenozoic of southern Australia. The primary substrate on much of the modern continental shelf is loose sediment that is reworked intermittently to $200+m$ water depth by storm waves. Availability of stable substrate is a limiting factor in the modern distribution of bryozoans in this setting. As a result, a significant proportion of the sedimentologically important modern bryozoans (30-250 m water depth) live attached to sessile, benthic invertebrate hosts that possess organic or spicular skeletons. Hosts such as hydroids, ascidian tunicates, sponges, soft worm tubes, octocorals, and other lightly-calcified and articulated bryozoans provide ephemeral substrates; after death, host skeletons disarticulate and decay, leaving little or no body fossil record.

The calcareous sediments produced by these epizoic bryozoans from ephemeral substrates result in loose particles that rarely preserve substratal relationships, but potentially retain diagnostic basal attachment morphologies. Although the best known examples of epizoic carbonate production on ephemeral substrates are from the southern Australian margin, this may be an important phenomenon both globally and in the fossil record. Bryozoan sediment production from epizoans on ephemeral substrates would seem, however, to have a scant record prior to the Cretaceous.
\end{abstract}




\section{ARTICLE}

\section{INTRODUCTION}

Observations from multiple sedimentological, oceanographic research investigations (James et al., 1992, 1994, 1997; unpublished data) suggest that a large proportion of the sediment production from the southern Australian cool-water province is not from organisms living in the sediment or on hard substrates. Rather, production is from calcareous bryozoans, foraminifers, and worm tubes living on other animals with organic, spiculate or articulated skeletons, such as sponges, hydroids, ascidian tunicates, octocorals, soft worm tubes, and other lightly-calcified and articulated bryozoans. Such hosts provide ephemeral substrates; specifically, when hosts decay or disarticulate they leave no obvious trace in the rock record, and calcareous epizoans are released as free sedimentary particles.

In terminology used herein, epizoans are organisms that grow on animal hosts, whereas epiphytes are organisms that grow on plant hosts. Epibiont is a more general term that describes either; see Davis (1998) for other use of this terminology. Sediment production by epiphytes from ephemeral substrates is well documented from sea grass and algal hosts (Land, 1970; Patriquin, 1972; Pestana, 1985; Nelson and Ginsburg, 1986). Living bryozoans are commonly observed as epizoans (Gautier, 1962; Schopf, 1969; Stebbing, 1971; Cook, 1979; Gordon, 1984; Hayward and Ryland, 1991; Barnes, 1994, 1995a, 1995b), but have not been regarded generally as a significant source of carbonate sediment. For example, Schopf (1969; fig. 4) observed 25 to 50 percent of bryozoans, whose substrate could be determined, living on hydroids in water depths of 25 to $125 \mathrm{~m}$ off the New England coast. Although carbonate production from epizoic foraminifers, serpulid worms, bivalves, brachiopods and solitary corals is important on the southern Australian shelf, all are secondary in volumetric significance to bryozoans. Only contributions from bryozoans living on animal hosts with organic or spiculate skeletons (ephemeral substrates) will be treated here.

A new term, epiathroic association, is introduced to describe the system of a host plus all of its epibionts; (epi = Gr. "living on top of " + athroos = Gr. "together, collected"). The host may be animal or plant, but must have an organic, spiculate, or articulated skeleton that is easily decayed. Such a term is needed to differentiate between the ecological relationships among epibionts and their living, ephemeral bodied hosts, versus epibionts growing on more robust skeletal hard parts, such as shells whose host may have been living or dead.

The purpose of this paper is four-fold: (1) to introduce and discuss the hypothesis that calcareous epizoans growing on ephemeral substrates (benthic animals with organic or spicular 
skeletons) account for a significant amount of carbonate sediment production in some coolwater settings; (2) to document the ecology and distribution of epizoic bryozoan growth on ephemeral, host substrates in southern Australia; (3) to provide criteria by which ephemeral substratal relationships can be recognized from fossil bryozoan sediments; and (4) to discuss the implications for interpretation of bryozoan-dominated rocks globally and throughout the Phanerozoic.

\section{GEOLOGICAL SETTING}

The continental margin of southern Australia is the largest east-west trending area of modern cool-water (less than $20^{\circ} \mathrm{C}$ ) carbonate deposition on the globe (Fig. 1). The shelf, which ranges from 25 to $200 \mathrm{~km}$ wide, extends east-west for more than 4,000 km, lies mostly in waters from 50 to $150 \mathrm{~m}$ deep, and is open to Southern Ocean swells and storms. The great depth of wave, swell, and storm-wave base on this shelf, which is exposed to effects of storms generated in the "roaring 40's," plays an important role in characterizing the ecosystem and depositional system (James et al., 1997). An idealized profile of the southern Australian margin is divided into five regions: shoreface, inner shelf, middle shelf, outer shelf, and upper slope (Fig. 2; Table 1).

The carbonate sediments in this regioN are wholly skeletal, produced largely by bryozoans, foraminifers, molluscs, and calcareous red algae; echinoids, azooxanthellate corals, brachiopods, and worm tubes are common but less important (Conolly et al., 1970; Jones and Davies, 1983; James et al., 1992; Boreen and James, 1993; James et al., 1994; James et al., 1997). Of the calcareous invertebrates on the open shelf and upper slope, bryozoans are by far the most important in terms of taxonomic diversity (455+ species identified; P.E. Bock, pers. comm. and abundance of carbonate sediment produced. Carbonate mud is produced as a byproduct of endolithic boring activity and as spicules from the many ascidian tunicates, sponges, and octocorals on the shelf. Most of this mud is transported off the shelf and deposited on the slope (James et al., 1994; Passlow, 1997).

\section{MATERIALS}

Data for this study come from three sources: (1) Material recovered from 357 bottom sample sites from four cruises of the R.V. Franklin across the southern Australian continental margin 
(Fig. 1; Lacepede Shelf 1989 and 1991, Lincoln Shelf 1994, and the Southwest Shelf and Great Australian Bight 1995). Data from these sites included: (a) Recent to relict Pleistocene skeletons in carbonate sedimentary samples recovered with a pipe dredge or epibenthic sled (specimens reposited at the University of Adelaide); (b) live specimens recovered with epibenthic sled or beam trawl and either preserved dried and in alcohol (South Australia Museum), or (c) observed on board ship but not retained; and (d) still photographs of the sea floor from 64 sample sites, representing most regions of the shelf.

(2) Individual specimens and their hosts were studied from dried and spirit collections of the South Australian Museum (3000+ specimens). Live specimens, collected by a number of museum divers with SCUBA, were from $<20 \mathrm{~m}$ along South Australia, Victoria and Tasmania, (South Australia Museum).

(3) Abundant, diverse, well preserved bryozoan skeletal material from the Glenforslan Fm. (Middle Miocene, Murray Basin, Morgan region, South Australia; Fig. 1) was investigated to determine the applicability of drawn conclusions to fossil material. The coarse fraction (>1 mm) from 150-mg bulk samples was used from two stratigraphic horizons collected at each of two correlated sections $\sim 12 \mathrm{~km}$ apart. Geographic location, sedimentologic and stratigraphic descriptions are given for sites CM-1.0, CM-5.3 (Cadel Formation type locality), WOOS-2.6, and WOOS-4.6 (Woods Flat) in Lukasik and James (1998).

\section{EVALUATION OF DATA}

The hypothesis presented in this paper-that carbonate produced by epizoic bryozoans growing on ephemeral substrates is a significant sediment source-was partially developed a posteriori on the basis of qualitative examination of thousands of modern bryozoan specimens (living and dead).

Data were evaluated and assessed in several ways.

(1) Ecological observations were made for dredged material brought on deck during the Lincoln Shelf and Great Australian Bight R.V. Franklin cruises (Fig. 1). Qualitative assessment of substrate predominance was made for the bryozoan faunule at each sample site. Substrate types included hard primary (bedrock or hardground), hard secondary (lithoclasts, large bioclasts), particulate, live animal host, and live plant host. In addition, a qualitative comparison 
was made of the faunal composition of the live benthic biomass versus the carbonate skeletal accumulations in the region.

(2) A variety of invertebrate biological specimens from all R.V. Franklin cruises and many other macroinvertebrates from the collections of the South Australian Museum were evaluated to determine the types of animal hosts that serve as substrates for epizoans.

(3) Twenty-five host invertebrate specimens were selected to assess the abundance and taxonomic diversity of epizoans living on each host. Preferences of host-types also were evaluated for each bryozoan species present.

(4) The growth-habit characteristics of epizoic bryozoans were noted for the twenty-five epiathroic associations (host and all its epizoans) to determine whether a correlation exists between certain growth-habit features and an epizoic life mode.

(5) Material from the four Murray Basin Miocene bulk samples were evaluated as follows. Unito multilaminate sheet specimens ( = encrusting sensu Hageman et al., 1998) were picked, sorted to species, and counted using an Olympus SZX12 stereo-microscope. Encrusting forms were additionally separated as to whether they were rooted, had grown free of their substrate, displayed signs of ephemeral basal attachment, or were still attached to their hard substrate. Substratal relationships also were diagnosed for rare erect specimens that still retained basal attachment structures. Representative specimens were selected for scanning electron micrography.

\section{RESULTS FROM RECENT MATERIAL}

\section{Shipboard Ecological Observations from Bulk Material}

The most abundant bryozoans across the southern Australian shelf are ones that can tolerate the particulate primary substrate that is mobilized intermittently even at water depths of $200+\mathrm{m}$. These include erect, rooted forms (e.g., Catenicella, Orthoscuticella, Cellaria, Adeona) that can stabilize sediment, and free-living forms (e.g., Selenaria, Otionella), many of which can shed or move through sediment.

Other carbonate sediment-producing bryozoans occur as epizoans on larger benthic invertebrates on the inner shelf to upper slope. Proportionally, skeletal remains on the shelf do not reflect the nature of the living benthic biomass. On the shelf, living sponges, hydroids, 
tunicates, and octocorals are volumetrically more abundant than living bryozoans. The sediment, however, is dominated by the skeletons of bryozoans (up to $80 \%$ ), with only minor representation from larger benthic invertebrates that serve as hosts (typically < 5\%).

The presence of hardgrounds (hard, primary substrate) is inferred in the region (James et al., 1992). Collecting methods, however, do not allow for direct sampling of hardgrounds. Large lithoclasts, 5 to $15 \mathrm{~cm}$, were recovered rarely from some localities (e.g., James et al., 1997). However, these secondary hard substrates usually are covered, in part or whole, with cemented encrusting bryozoans (sheets). Abundant encrusting forms tend to constructively enlarge the clast rather than produce loose sedimentary particles. Erect, rooted and stalked bryozoans, such as Cellaria, Catenicella, and Adeona, were present on large lithoclasts. Large lithoclasts are found primarily in water less than $55 \mathrm{~m}$ deep (within abrasion wave depth) on the southern Australian shelf.

Medium-sized, 1 to $5 \mathrm{~cm}$, bioclasts are locally abundant (usually gastropod and pelecypod shells) and typically have isolated, small runners and spots of encrusting bryozoans. These bioclasts occasionally support abundant encrusting bryozoans, but only rarely support erect bryozoans. This suggests that these medium sized bioclasts, which would serve as favorable substrates for bryozoans in other settings, are reworked by swell and storm waves too frequently on the southern Australian shelf to support a sediment-producing bryozoan fauna. Rare, isolated, large bioclasts support encrusting, rooted and minor erect bryozoans.

\section{Hosts for Epizoans}

Bryozoans grow as epizoans on a variety of sessile benthic invertebrates on this shelf. The array of hosts includes sponges (Fig. 3G), ascidian tunicates, flexible and articulated bryozoan colonies (Fig. 3A, F), plumulariid hydroids (Fig. 3D), gorgonian octocorals, and soft tubes of polychaete worms (Fig. 3B).

Bryozoans themselves also play an important role in providing ephemeral substrates for other bryozoans, benthic foraminifers, and calcareous worm tubes. Uncalcified ctenostome bryozoans are abundant on the southern Australian shelf and commonly serve as ephemeral substrates for many other bryozoan species (Fig. 3E). Likewise, other weakly calcified but bushy bryozoans (e.g., Bugula, Beania, Dendrobeanina, Carbasea, and Flustra) are hosts for more heavily calcified forms, but only rarely leave a fossil record themselves.

Many bryozoans produce non-living (degenerated) extrazooidal calcareous skeleton and/or, large non-feeding kenozooids of cuticular tubes that function as either a means of colony attachment (roots) or as flexible support. Such cuticular tubes or rootlets, which decay after 
death, typically serve as substrates for other bryozoans and sessile invertebrates. The greatest diversity, and potentially total volumetric importance, of epizoic bryozoans is found on articulated zooidal colonies such as Catenicella, Orthoscuticella, Pterocella, and Scuticella (Table 2, Fig. 3A, F). Articulated branching bryozoans such as Cellaria, Margaretta, and Quadriscutella typically act as hosts for other bryozoans. However, these forms do not support as many epizoic colonies as soft-bodied or articulated zooidal hosts (Table 2). Large and diverse bryozoan colonies also grow on the articulated stalks of the bryozoan Adeona (Fig. 3C, Table 2). When Adeona dies, these stalks disarticulate.

Much of the sea floor is dotted with diverse and complex epiathroic associations (Fig. 3). Relationships between primary and secondary hosts are often multi-generational and layered (e.g., ascidian tunicates growing on rooted bryozoans, which are growing on sponges, any of which may serve as host to small epizoans). Species succession and over-growth relationships vary, but a single epiathroic association can potentially propagate beyond the life of any individual host (decades?) and, thus, may produce several generations of epizoic carbonate sediment throughout the lifetime of the epiathroic association. The effects of sediment accumulation by baffling from these epiathroic associations was not evaluated.

\section{Growth-Habit Characteristics of Epizoic Bryozoans}

It has long been argued that the life mode of a bryozoan colony is reflected in the morphology of its growth habit (Stach, 1936). Characteristics of bryozoan growth habits (Fig. 4) can be summarized in terms of eleven features (Hageman et al., 1998; figs. 3 and 4): (1) orientation, (2) attachment, (3) construction, (4) arrangement of zooecial series, (5) arrangement of frontal surfaces, (6) secondary skeletal thickening, (7) geometry of structural units, (8) dimensions of structural units, (9) frequency of bifurcation, (10) dimensions of bifurcations, and (11) connection of structural units.

The vast majority of all realized combinations of growth-habit characteristics can be found growing in an epizoic habit on the southern Australian shelf (Fig. 4). The general lack of correlation between growth habit characteristics and epizoic habit is an important characterization in itself. The growth-habit characteristics that do provide significant clues to an epizoic life mode are those related to the attachment of the bryozoan to its substrate. The freeliving growth-habit (e.g., Selenaria) and certain pedunculate forms (e.g., Sphaeropora) were the only growth-habit characteristics that were not observed in epizoic growth in this study. Note that is does not mean that all taxa were observed as epizoans, only that the vast majority of growth-habit characteristics were observed in epizoic taxa. 


\section{Survey of Selected Epiathroic Associations}

Twenty-five epiathroic associations from five southern Australian shelf localities were examined. The host type and number of observed epizoic bryozoan species on each are summarized in Table 2. All of these epiathroic associations were collected from the inner-middle shelf of the Great Australian Bight and the Lincoln Shelf (65-154 m water depth).

In the material examined, individual, epizoic bryozoan species are not restricted to a specific host type. No bryozoan growth habit is particularly diagnostic of (restricted to or omitted from) an epizoic life mode. The diversity (both taxonomic and growth-habit variation) within a single epiathroic association varied from one to several tens of bryozoan species (Table 2). Abundance ranged from a single epizoic colony to hundreds of colonies per host organism.

\section{CRITERIA FOR THE RECOGNITION OF FOSSIL EPIZOANS: AN EXAMPLE FROM THE AUSTRALIAN MIOCENE}

An individual, randomly chosen bryozoan skeletal fragment is unlikely to contain the information required to make a meaningful diagnosis of its original substrate. In addition, most of the characteristics given below also can be derived from hard substrates. However, fossil epiathroic associations can be recognized with varying degrees of confidence in cases where large numbers of specimens are evaluated, and signals from multiple criteria support an epibiontic interpretation (Figs. 5, 6; Table 3).

\section{Epizoan versus Epiphytic Growth Habit}

In general, epibionts from ephemeral hosts exhibit many of the characteristics discussed in the sections below. In practice, however, it can be difficult to distinguish between epizoic and epiphytic colonies based on skeletal hard parts alone. Detailed criteria for distinguishing between epizoic and epiphytic skeletal material have not been established previously. Two general features that may be useful for making the distinction between epizoic and epiphytic faunas are: (1) in some cases, the identity of the host can be determined based on details of bioimmured attachment surfaces that preserve the exterior texture of the host (see below); and (2) paleoenvironmental reconstructions, based on independently derived data, can suggest whether a setting was below local photic zone. 


\section{(1) Bioimmuration}

When bryozoans cement to the irregular surface of a host invertebrate, the basal attachment surface may preserve the exterior texture of the host in moldic relief. This method of preservation is called bioimmuration (Voigt, 1979; Taylor, 1990). If preserved in enough detail, the bioimmured surface may allow for identification of the host. For example, Voigt (1981, fig. 2; also fig. 7.11 in McKinney and Jackson, 1989) was able to identify the sea grass Thalassocharis bosqueti bioimmured by Late Cretaceous bryozoans, and Taylor (1990, figs. 1, 2) identified a bioimmured Cretaceous ventriculitid sponge as the host for a pelecypod.

The surface texture of hosts can be seen in many Miocene, Glenforslan epizoic bryozoans (Figs. 5A, 6B, C, D, E, H). Many of these specimens appear to have been attached to bryozoan hosts, although the identity of hosts even to phylum level, is uncertain at this time. Scanning electron microscopy was required to recognize the presence of most of these bioimmured textures (e.g., Fig. 6B and E), but others are more obvious (Fig. 6D). Identification of "softbodied" hosts based on bioimmured textures remains relatively problematic (e.g., Rohr and Boucot, 1989; Taylor, 1990). Nevertheless, it seems a promising topic for further investigation.

\section{(2) Basal Wall Structure}

When bryozoans grow as epibionts, their basal wall often is formed very thinly or is partially missing (Voigt, 1973). This can be seen on well preserved Glenforslan specimens, where the basal wall thins, yet retains its flat surface that originally abutted to the host substrate (Fig. 6G, $H, I)$. Such delicate preservation would not be expected in cases where a colony was torn from a position cemented to a hard substrate.

When encrusting bryozoans grow free from their substrate (encrusting defined as sheet forms, regardless of attachment type), the basal wall takes on a distinctive pustulose or billowy texture. Growth lines and linear, zooecial zones are clearly evident (Fig. 6C, H). Combinations of these wall types can be seen on many Glenforslan specimens, outlining areas of attachment to the ephemeral host and regions of growth free from the host substrate (e.g., Figs. 5A, D, E, F, G, H, $6 \mathrm{~B}, \mathrm{C}, \mathrm{F}, \mathrm{G}, \mathrm{H})$. The branching nature of a host can be seen in the bifurcations of the contact surfaces on some specimens (Fig. 6C, H).

This mixed basal wall type also can be produced in encrusting bryozoans that are otherwise cemented to a hard substrate, but that rise up from their substrate and grow free for a time (McKinney and Jackson, 1989). However, this mixed wall type is the expected state in most all epibiotic encrusting forms, especially those on erect, arborescent hosts. Large encrusting sheets appear to be "draped" over the branches of a bushy host (Fig. 3E). Presence of many of 
these mixed basal wall morphologies in the Glenforslan specimens provides a line of evidence for the faunas epibiontic origin (Table 3).

\section{(3) Basal Attachment Morphology}

The shape and nature of the basal attachment structures as discussed below are some of the most diagnostic characteristics for recognizing epibionts from skeletal material. However, the mere presence of large numbers of bryozoans (encrusting or erect; cemented or rooted) that are found free from their substrate, reflects that the specimens originally were attached to ephemeral substrates. Basal surfaces otherwise are attached firmly to their original hard substrate.

This is the case for the sediment of the Miocene Glenforslan Fm. of the Murray Basin, South Australia. Of all encrusting forms present in the $>1 \mathrm{~mm}$ split of four $150 \mathrm{~g}$ bulk samples, $74 \%$ possessed basal attachments free of their substrate, whereas only $26 \%$ of the encrusting forms were attached to hard substrates (Table 4). Most of the bryozoans attached to hard substrates were small runners or spots (i.e., not sediment producers). Most of the bioclasts were other bryozoans (Table 4), many of which were themselves included in the probable epibiont category.

\section{(3a) Flat Basal Surfaces}

A simple, but important morphological characteristic is the especially flat basal surfaces produced by many epibiontic bryozoans (Fig. 6A, B, D, E, F). These flat surfaces result when epizoans conform to the generally broad uniform surface of larger hosts. These relatively smooth attachment surfaces, which are a coarser scale of bioimmuration, may or may not preserve the details of host surface texture. Flat or broadly curved attachment surfaces are preserved more frequently in the Glenforslan material than hold-fast ring structures discussed in the next section.

\section{(3b) Engulfed Host}

In instances where an epizoan entirely or mostly surround a host, the host substrate must have been alive, or at least erect at the time (Fig. 5B, C, D, E, F). For example, such occurrences can result in a host as an apparent "stick" driven through an epizoan "nodule" (Fig. 5C), or extrazooecial skeleton of the epizoan engulfing its host (Fig. 5F). Similar interpretations can be made for moldic preservation of an ephemeral host, when the host is mostly or entirely engulfed by an epizoan (Fig. 5D). Surrounded or engulfed hosts are common in Glenforslan material (Table 3). 
In some cases, bryozoans that attach to ephemeral substrates can produce a complete mold of the contact region with its host; for example, a hold-fast may form a ring as it encompasses an erect stalk or stem (Voigt, 1973; plate II, fig. 1; Voigt, 1981; fig. 1H). Although such structures commonly are observed in living material (Fig. 3E), the back side of wrap-around, or ring, structures are often delicate, and such structures observed in Miocene Glenforslan material rarely survived otherwise routine ultrasonic cleaning.

Ad hoc explanations can be called upon to interpret encrusting growth of greater than $180^{\circ}$ around a bioclast. However, barring clear evidence for an unusually perched bioclast, or the overturning of a bioclast and redirected growth of the bryozoan around it, the most parsimonious explanation is one of an epibiont growing on an erect host.

\section{(3c) Free Growth Surrounding Host}

An interpretation of an erect (living?) host also can be made for bryozoans that wrap or curve around their host in regions where the bryozoan has grown free from its substrate (Figs. 3E, 5A, $\mathrm{H}, 6 \mathrm{~J})$. This arrangement is most easily explained if the host was erect at the time, which would provide free space into which the bryozoan could grow around and behind the host. Free growth surrounding a host is common in Glenforslan material.

\section{(3d) Pores for Rootlets}

On the modern southern Australian shelf, rooted, encrusting-sheet bryozoans (e.g., Mucropetraliella, Hiantopora, Parastichtopora) most commonly were found living on flexible, organic substrates. The hair-like rootlets that protrude from the basal wall of these forms allows them to occupy an irregular, flexible substrate that is in motion due to wave or swell action. The skeletons of these rooted, sheet bryozoans typically display pores on their basal wall, from which their cuticular rootlets are budded (Fig. $5 \mathrm{H}, \mathrm{I}, \mathrm{J}$ ). Rooted, encrusting-sheets are common to abundant in Glenforslan material, suggesting an epibiontic interpretation.

\section{(4) Preserved Articulated Hosts}

If multiple elements of an articulated host can be seen on the basal attachment surface of a bryozoan, this indicates that the host was alive, erect, or at least that the host's articulating tissues had not yet decomposed at the time that the epizoan grew. The articulated elements may be preserved in place (Fig. 5B), or as bioimmured molds (Fig. 5A). Such specimens are rare in the Glenforslan material, but their presence is an especially strong indicator of epiathroic associations. 


\section{(5) Pseudoviniculariform}

Some bryozoans that appear to exhibit erect growth habits, are actually hollow-cylinders formed by an otherwise encrusting bryozoan that surrounds the stalk or stem of a host (Stach, 1936). Some encrusting bryozoans may then continue to grow as a cylinder beyond the end of host (Fig. 3D). In mature colonies, this can result in very regular, (determinant?) erect arborescent forms with hollow branches (Fig. 5F, G). Stach (1936) named these "pseudoviniculariforms," as distinct from proper viniculariforms which have thin, solid cylindrical branches, supported by their own basal attachment structures. The presence of abundant pseudoviniculariforms in Glenforslan material suggests prevalent epibiontism.

\section{(6) Presence of Potential Hosts}

The presence of many rooted, erect flexible or articulated bryozoans (e.g., Catenicella, Cellaria, Caberea), which typically serve as hosts for other bryozoans, invites an investigation for associated epizoans (Fig. 5A, C). Although small spicules are prone to reworking, evidence of spiculate hosts such as sponges, octocorals (Fig. 5B), and ascidian tunicates (cf. Brookfield, 1988) also is indicative of the potential presence of epiathroic associations. In Glenforslan sediments, ascidian spicules, and internodes from articulated zooidal and articulated branching bryozoans are common, and octocoral spicules are present. Thus, potential hosts for epiathroic associations are clearly abundant in the Glenforslan Fm.

\section{(7) Used and Unused Substrates}

The presence of many bioclasts that are not encrusted with bryozoans indicates that bioclasts were not the principle substrate of the bryozoans. In the Glenforslan material (Table 4), $84 \%$ of the bioclasts in the size fraction studied did not host a bryozoan. No lithoclasts are present in this material.

The Glenforslan ratios of 3:1 for probable epizoans to hard-substrate-encrusters, and 5:1 for non-encrusted bioclasts to encrusted bioclasts, suggests that the particulate sediment was not stable (being reworked) and that the bryozoans resorted to living as epizoans. However, similar calculations need to be performed for known occurrences in modern settings to establish cutoff values for more meaningful interpretations.

\section{Summary of Miocene Glenforslan Data}

The Middle Miocene Glenforslan material from the Murray Basin of South Australia provides supporting evidence from all seven criteria listed above, and subcategories therein, for the presence of abundant epiathroic associations. This suggests that much of the carbonate sediment in the unit was derived from epiathroic associations. Although an epizoic interpretation 
is favored based on evidence from bioimmured hosts, a more detailed study of this material is needed to provide a definitive assessment.

\section{DISCUSSION}

\section{Advantages of Epizoic Growth-Habits}

Why are so many southern Australian bryozoans living as epizoans? The primary ecological advantage provided to such epizoans, relative to their epibenthic counterparts, is increased availability of suitable substrate. The substrate over much of the southern Australian shelf is particulate (silt to coarse sand), which is regularly reworked by deep storm waves and background swells. Large, sessile, benthic invertebrate hosts provide a greatly expanded potential surface area to be exploited, especially when the hosts are pioneers in an ecological setting with unfavorable primary substrates for the epizoans.

In depositional settings where the substrate is not as disrupted frequently at great depths by storm waves, the pressure for available stable substrate would be reduced, resulting in the more familiar occurrence of bryozoan colonies growing on shells and other small bioclasts and lithoclasts. That is, the large invertebrates could still be viable candidates as host substrates, but the total surface area provided by the primary substratum would diminish the significance of animal hosts in a random selection of stable substrate. In consequence, encrusting bryozoans cemented to hard substrates would not be released as loose sedimentary particles like their epizoan counterparts.

Another advantage of an epizoic growth-habit for suspension feeders is that it provides a higher position in the water column relative to their benthic counterparts and, thus, greater access to nutrients, regardless of their size or orientation of the colony. For example, on the same primary substrate, an erect bryozoan may grow advantageously above the boundary layer occupied by encrusting bryozoans. However, the same encrusting bryozoan growing high on a larger benthic host, may have a significant advantage over its erect counterpart restricted to the primary substrate. Therefore, recognition of the pervasiveness of epibiontism would be important in studies of trophic tiering for bryozoans (Bottjer and Ausich, 1986).

\section{Consequences for Sediment Production from Epizoans}

The ecology and taphonomy of epizoans growing on ephemeral substrates has received little formal treatment. Sediments derived from calcareous epizoans growing on ephemeral substrates, however, do possess some specific properties: (1) sediments are released 
automatically as loose particles (jumbled but potentially well preserved), and rarely are preserved with their original relationship to their substrate intact (non-binding, nonconstructional); (2) the distribution and sediment composition may be controlled strongly by the ecology of the original host organism (in addition to the ecology of the sediment producer); and (3) this study suggests that carbonate sediment production from epiathroic associations potentially is much greater than that from the underlying area of shifting particulate substrate alone (occupied by free-living and interstitial forms only).

On the modern shelf, live epiathroic associations are locally abundant, forming patchy "meadows" among vast, otherwise barren areas (Fig. 7A and B versus $\mathrm{C}$ ). The local sediment production from productive patches is likely distributed across the shelf under storm-wave conditions. The distribution of barren zones, versus isolated epiathroic associations, versus productive epiathroic patches, suggests that intermittent, intense storm episodes (on the decade scale?) may be a control on the distribution of epizoic sediment production on the southern Australian Shelf.

\section{Potential Rates of Epizoic Sediment Production}

It is difficult empirically to document rates of carbonate sediment production from epizoans due to problems associated with standardizing field collection, the wide range of specimen sizes (six orders of magnitude), and poorly known rates of bryozoan growth and carbonate production. Sediment production can, however, be modeled as a function of long-term population averages:

$$
K=(n * v) / 10 t
$$

where $K=$ the production rate in centimeters per thousand years $(\mathrm{cm} / \mathrm{ky}), n=$ average number of epizoic bryozoan colonies per square meter, $v=$ average size of the epizoic bryozoan colonies (in cubic centimeters), and $t=$ number of years required for the average colony to grow to its mortal size. The value of 10 in the denominator is the result of calculating rates in terms of 1,000 yrs over 1 square meter (10,000 sq. cm). This model does not account for sedimentaccumulation rates, which are additionally a function of transportation and taphonomy (Smith and Nelson, 1996).

Two questions can be asked. (1) What values for these parameters would be required to generate a significant amount of carbonate sediment? (2) Are these values in concordance with observations made about epizoic bryozoans within and among epiathroic associations? For example, with values of average bryozoan skeleton size of $v=0.027 \mathrm{~cm}^{3}\left(3 \mathrm{~mm}^{3}\right)$, a turnover period of $t=3$ years, and number of specimens per square meter of $n=4,000$, a sediment production rate of $K=3.6 \mathrm{~cm} / \mathrm{ky}$, can be calculated. A value of $K$ in this range was chosen 
because the rate of sediment accumulation on the shelf is estimated to be $1-10 \mathrm{~cm} / \mathrm{ky}$ (Wass et al., 1970; James et al., 1992). This example provides values for comparison; direct relationships between epizoic sediment production and cool-water sediment accumulation are not implied here.

Bryozoan colonies vary greatly in their size, from less than a millimeter to potentially well over 10 centimeters in length, providing an expected range of $v=0.001$ to $10 \mathrm{~cm}^{3}$. The selected value of $v=0.027 \mathrm{~cm}^{3}$ ( $3 \mathrm{~mm}^{3}$, including pore space), is smaller than most of the epizoic bryozoans shown in Figure 3, which are typical of observed epiathroic associations. Ages for large, perennial bryozoan colonies have been recorded as 1.5 yrs for English Channel Cellaria sinuosa (Bader, in press), 3+ yrs for Pentapora foliacea from the Irish Sea (Pätzold et al., 1987), 12 yrs for Flustra foliacea off South Wales (Stebbing, 1971), and up to 26 years for deep, Antarctic Alloeflustra tunuis (Barnes, 1995b). All of these bryozoans are considered to be larger, longer-lived, and known hosts for epizoic bryozoans. Bryozoan colonies are more commonly short-lived (annual or biennial; Pätzold et al., 1987). The life span of individual epizoic Bryozoa colonies (turn over) is estimated here to range from $t=1 \pm$ to 10 years; in part this is based on 15 years of recurrent SCUBA observations at sites in South Australia (K. Gowlett-Holmes, pers. comm.). The turnover period of deeper water epizoic bryozoans is unknown, but the selected value of $t=3$ years appears to be well within an expected range.

Due to the poor constraints on bulk sampling methods from deep water, values for $n$ (numbers of epizoic colonies per square meter) can only be speculated upon. To our knowledge, rates of carbonate production never have been calculated for epizoans, as they have been for more directly observable, shallow-water epiphytes (Pestaina, 1985). Cook (1979, fig. 1; also fig. 9.15 in McKinney and Jackson, 1989) observed more than 200 epizoic bryozoan colonies attached to a single polychaete worm tube, collected from $>200 \mathrm{~m}$ water depth, which itself occupied a maximum area of $10 \mathrm{~cm}^{2}$. Cook speculated that densities of over 20,000 epizoic colonies per $\mathrm{m}^{2}$ are possible among these hosts. It should be noted that small hosts for epiathroic associations such as Cook's (1979) worm tube, and most shown in Figure 3, are barely visible at the scale of Figure 7. Based on measured growth of 19 bryozoan species on settling tubes in New Zealand (10 of which have been observed as southern Australian epizoans), Smith and Nelson (1994) estimated that sediment production rates for these cool-water taxa are 4-40 $\mathrm{cm} / \mathrm{ky}$. Bader's (in press) calculation of 24 to $38 \mathrm{~g} / \mathrm{m}^{2} /$ year from Cellaria sinuosa of the English Channel yields an approximated sediment production rate of $4-6 \mathrm{~cm} / \mathrm{ky}$. On a single $10.5-\mathrm{cm}-$ high, 5-year old colony of Flustra from off the coast of South Wales, with a surface area of 560 cm², Stebbing (1971, fig. 1; also fig. 4.14 in McKinney and Jackson, 1989) counted 566 
calcareous epizoans. Note that these 566 epizoans were produced from a host whose basal attachment occupies less than $1 \mathrm{~cm}^{2}$ of the primary substrate.

Thus, the values $v=0.027 \mathrm{~cm}^{3} ; t=3$ years, $n=4,000$, and a sediment production rate of $K=$ $3.6 \mathrm{~cm} / \mathrm{ky}$, appear to be within reasonable limits, and suggest that a measurable contribution of sediment could be expected from epizoans. This is credible even in a setting with a much lower abundance of epiathroic associations.

\section{Substrate Selectivity of Epizoans}

Signals about bryozoan substrate preference are mixed. Specimens observed from the 25 epiathroic associations (Table 2) did not reveal a preference for organic substrate type. In general, bryozoans appear to use any available, suitable (stable) substrate. For this reason, substratal relationships are usually not recorded or systematically compiled in taxonomic literature. However, substrate preferences have been documented for epizoic bryozoans (Stebbing, 1971; Barnes, 1994, 1995a), suggesting that some epizoic species are highly discriminatory; for example, certain Celleporaria_digitate sponge associations are documented on the southern Australian shelf.

Ecological relationships between epizoic bryozoans and their hosts are varied, with known examples ranging from fouling (hosts used as obligate substrates), to commensal (epizoan benefits without affecting host), to symbiotic (Wahl, 1989; Taylor, 1994; Key et al., 1996). Some seemingly suitable host taxa (e.g., some sponge and ascidian tunicate species) from the southern Australian shelf are invariably free of epizoans (chemical, anti-fouling deterrents?), whereas other host species almost always have epizoans on their surface (e.g., several hydroid, sponge, and ascidian species, as well as many catenicellid and ctenostome bryozoan species). Individuals of other southern Australian host species variously may, or may not, have epizoans, possibly as a result of local conditions and recruitment.

\section{DISTRIBUTION OF EPIZOIC BRYOZOA INSPACE AND TIME}

\section{Recent Geographic Distribution}

Although reported occurrences of living bryozoans as epizoans are widespread, they are not reported as making significant sedimentary contributions. The morphology of many bryozoans in cool-water settings are consistent with epizoic life modes on ephemeral substrates: the southern Australian shelf (Wass et al., 1970; Hageman et al., 1996), including Tasmania (Marshall and Davies, 1978); parts of the New Zealand Shelf (Nelson et al., 1981; Carter et al., 1985; Nelson 
et al., 1988); the bryozoan shelf fauna off the coast of South Africa, 80-90 m water depth, $35^{\circ} \mathrm{S}$ (Hayward and Cook, 1983). The Antarctic shelf is well known for its cold-water mega-epibenthic fauna, dominated by sponges (White, 1984; Barthel et al., 1991). Many of the diverse bryozoan species are known to be epizoic, and their skeletons, along with sponge spicules, make up the bulk of the sediment in some areas (e.g., Barthel et al., 1991; White, 1984; Androsova, 1968, 1972; Winston and Hayward, 1994; Barnes, 1994, 1995a, 1995b).

The epizoan-dominated bryozoan faunas do not appear to be as well developed in the coolwater settings of the Northern Hemisphere. This may be due to widespread terrigenous sediment deposition during the most recent glacial episode, producing substrates unsuitable to bryozoans or their hosts (Milliman et al., 1972). There are, however, local settings of significant bryozoan sediment production from ephemeral substrates in the northern hemisphere, such as the shallow shelf $<75 \mathrm{~m}$ of the Kurile Islands, north of Japan $47^{\circ} \mathrm{N}$ (Gontar, 1981). Epizoic bryozoans also grow on ephemeral substrates (hydroids and sponges) on the submarine seamount Vesterisbanken, east of Greenland, $74^{\circ} \mathrm{N}$ (Henrich et al., 1992; Schäfer, 1994). In limited settings on the cool-water continental shelf off Ireland and Scotland, sediment is derived from epizoic bryozoans living as massive, encrusting spheres around hydroid stems (Farrow et al., 1984).

Through all latitudes, the life modes of many deep-water bryozoans ( $>500 \mathrm{~m}$ ) are rooted or associated with limited, commonly ephemeral substrates (Hayward and Cook, 1979, 1983; Cook, 1981; Gordon, 1987). Sediment production rates are relatively minor for these minute, deep-water bryozoan forms.

\section{Distribution in the Cenozoic}

This preliminary study of the Middle Miocene Glenforslan Fm., South Australia, indicates that epiathroic assemblages can be recognized in the Cenozoic. No other units have been evaluated using the criteria presented herein. However, the Glenforslan bryozoan taxa are typical of those throughout much of the Australian Cenozoic and, indeed, throughout the world. This suggests that in settings with particulate, unstable substrates, that similar epiathroic associations could have developed and were preserved.

It should be noted, however, that many of the bryozoan Families whose members can exist as epizoans, and the Families of many bryozoans that commonly act as hosts for these associations (many characterized by cuticular roots and/or articulated skeletons) originated in the Late Cretaceous or Eocene, (compiled from Taylor, 1993). The early Cenozoic ecological expansion of the Bryozoa means that actualistic interpretations applied to pre-Late Cretaceous material need to be made with caution. 


\section{Distribution through the Paleozoic and Mesozoic}

The known geologic record of calcareous epizoans from ephemeral substrates is anecdotal at this time from Paleozoic and most Mesozoic rocks (e.g., Glinski, 1956), with examples arising primarily from exceptionally well-preserved sponge hosts (Finks, 1960; Ziegler, 1964; Gundrum, 1979; Lenz, 1993). The reasons for this scant pre-Cenozoic record could be: (1) that evidence of these substratal relationships are not obvious, and have gone unrecognized; or (2) that epizoic growth on ephemeral substrates is truly a Cenozoic phenomenon and was of lesser significance in the Paleozoic and Mesozoic. Either interpretation has broad reaching implications. If pre-Cenozoic epizoans were significant but have remained unrecognized, then a broad program of reevaluation of benthic life modes, taphonomy, and paleoecology may be called upon to appreciate sediment production and paleoenvironmental analysis from many Paleozoic and Mesozoic settings. Alternatively, if pre-Cenozoic epizoans were of minimal importance, the actualistic sedimentological models based on Recent carbonate settings must be applied to the past with care.

If epizoans from ephemeral substrates are absent from Paleozoic and Mesozoic rocks, there are two possible explanations: (1) epizoic and host bryozoans may have developed in the Late Cretaceous, associated with a major radiation of cheilostome bryozoans; or (2) there may have been a lack of suitable host organisms during the Paleozoic and Mesozoic.

The considerable record of epizoic and epiphytic bryozoans from hard, preservable substrates demonstrates that the morphologic potential and capabilities for epibiontism did exist during the Paleozoic and Mesozoic (e.g., epiphytes: Alberstadt and Walker, 1976; Voigt, 1973, 1981; and epizoans on hard substrates: Alvarez and Taylor, 1987; Alexander and Brett, 1990; Lescinsky, 1997). This invites a more detailed evaluation of Paleozoic and Mesozoic bryozoan substratal relationships.

\section{SUMMARY}

Bryozoan skeletons are a dominant sedimentary constituent of the cool-water carbonate province of the Recent and Tertiary southern Australian margin. Many of the sedimentologically important bryozoans from this province live attached to larger sessile benthic invertebrate hosts that have organic or spicular skeletons (ephemeral substrates). Epizoic organisms from ephemeral substrates produce loose, carbonate sediment particles that rarely preserve substratal relationships. 
The sedimentological significance of these calcareous epizoans is much greater than previously realized. The occurrence of epizoans on ephemeral host substrates may be driven by the limited availability of stable substrate on the southern Australian shelf. These particulate substrates are reworked intermittently to $200+m$ water depth by storm waves and swells. Host invertebrates increase available surface area of stable substrata and, thereby, increase sediment production. The taphonomic implications for sediment derived from these processes need to be investigated further.

A wide variety of bryozoan growth-habit characters are observed in epizoans (e.g., encrusting, erect, branching, delicate, robust, articulated, cemented, rooted). Host substrates include hydroids, ascidian tunicates, sponges, soft worm tubes, octocorals, and other bryozoans. Bryozoan species present are not highly selective and apparently settle on any stable organic or inorganic substrate. Therefore, environmental controls over the distribution of host organisms also influence the distribution of calcareous epizoic bryozoans (sediment production).

Epizoic life modes can be inferred from sedimentary particles (fossils) based on analysis of key morphological features. These include bioimmuration, attached or unattached basal walls, engulfed or surrounded hosts, pores for rootlets, flat basal surfaces, and presence of pseudoviniculariforms and articulated or spiculate hosts.

Sediment production from epizoans on ephemeral substrates has a scant record prior to the Cenozoic. This possibly is associated with the radiation of many cheilostome bryozoan clades, not occurring until the Late Cretaceous or Eocene, or the failure to recognize the life mode in earlier forms.

\section{Acknowledgments}

We thank P. Bock (Royal Melbourne Institute of Technology), J. Lukasik (Queen's University), and K. Gowlett-Holmes (South Australian Museum) for helpful discussion; and the Marine Invertebrates Section of South Australia Museum for use of facilities and their assistance, which greatly facilitated this project. We thank two anonymous reviewers whose comments and suggestions improved this paper. This research is funded by the Australian Research Council and the Natural Sciences and Engineering Research Council of Canada. We thank CSIRO Division of Oceanography and the Captains and crew of the R. V. Franklin for their support during cruises on which these samples were collected. We thank the Field Museum of Natural History and the Appalachian State University Research Council for support of this project. 


\section{REFERENCES}

Alberstadt, L. P. and K. R. Walker. 1976. A receptaculitid-echinoderm pioneer community in a Middle Ordovician reef. Lethaia 9:261-272.

Alexander, R. R. and C. E. Brett. 1990. Symposium on Paleozoic epibionts: Introduction. Historical Biology 4:151-153.

Alvarez, F. and P. Taylor. 1987. Epizoan ecology and interaction in the Devonian of Spain. Palaeogeography, Palaeoclimatology, Palaeoecology 61:17-31.

Androsova, E. I. 1968. Mshanki otriadov Cyclostomata i Ctenostomata Antarktiki i Subantartktiki. Resultati Biologicheskij Issledovanii Sovetskoi Antarkticheskoi Ekspedistii (19551958 gg) 4:35-84.

Androsova, E. I. 1972. Mshanki Cheilostomata Anasca Antarktiki i Subantartktiki. Resultati Biologicheskij Issledovanii Sovetskoi Antarkticheskoi Ekspedistii (1955-1958 gg) 5:315-344.

Bader, B. in press, Life cycle, growth carbonate production of Cellaria sinuosa: in Herra, A., Jackson, J.B.C., eds., Proceedings of the $11^{\text {th }}$ Meeting of the International Bryozoology Association, Panamá, January 1998.

Barnes, D. K. A. 1994. Communities of epibiota on two erect species of Antarctic Bryozoa. Journal of the Marine Biological Association of the United Kingdom 74:863-872.

Barnes, D. K. A. 1995. a. Epibiotic communities on sublittoral macroinvertebrates at Signy island, Antarctica. Journal of the Marine Biological Association of the United Kingdom 75:689703.

Barnes, D. K. A. 1995. b. Seasonal annual growth in erect species of Anatarctic bryozoans. Journal of Experimental Marine Biology Ecology 188:181-198.

Barthel, D., J. Gutt, and O. S. Tendal. 1991. New information on the biology of Antarctic deepwater sponges derived from underwater photography. Marine Ecology Progress Series 69:303307.

Boreen, T. D. and N. P. James. 1993. Holocene sediment dynamics on a cool-water carbonate platform. Otway, southeastern Australia: Journal of Sedimentary Petrology 63:574-588.

Bottjer, D. J. and W. I. Ausich. 1986. Phanerozoic development of tiering in soft substrata suspension feeding communities. Paleobiology 12:400-420. 
Brookfield, M. E. 1988. Where are all of the fossil sea squirts? Micropaleontology 34:277-283.

Carter, R. M., L. Carter, J. J. Williams, and C. A. Lands. 1985. Modern and relict sedimentation on the South Otago continental shelf, New Zealand. Memoirs of the New Zealand Oceanographic Institute 93:1-43.

Conolly, J. R., A. Flavelle, and R. S. Dietz. 1970. Continental margin of the Great Australian Bight. Marine Geology 8:3-35.

Cook, P. L. 1979, Mode of life of small, rooted "sand fauna" colonies of Bryozoa: in Larwood, G.P., and Abbott, M.B., eds., Advances in Bryozoology: Academic Press, London, p. 269-282.

Cook, P. L. 1981. The potential of minute bryozoan colonies in the analysis of deep sea sediments. Cahiers de Biologie Marine 22:89-106.

Davis, R. A. 1998. Humpty Dumpty's glossary of epizoa and suchlike: compiled for the symposium "Ecology and Evolution of Encrusting and Boring Organisms" at the Annual Meeting of the North-Central Section of the Geological Society of America, Columbus, Ohio: privately published, $39 \mathrm{p}$.

Farrow, G. E., N. H. Allen, and E. B. Akapan. 1984. Bioclastic carbonate sedimentation on a high-latitude, tide-dominated shelf. NE Orkney Islands, Scotland: Journal of Sedimentary Petrology 54:373-393.

Finks, R. M. 1960. Late Paleozoic sponge faunas of the Texas region. Bulletin of the American Museum of Natural History 120:1-160.

Gautier, Y. V. 1962. Recherches écologiques sur les Bryozoaires chilostomes en Mediterranée occidentale. Recueil des Travaux de la Station marine d'Endoume, Faculté de Sciences de Marseille 38:434.

Glinski, A. 1956. Plumalina conservata n. sp. (Gorgonaria) aus dem Mittel-Devon der Eifel. Senckenbergiana Lethaea 37:53-57.

Gontar, V. J. 1981, On the Cheilostomata (Bryozoa) of the Kurile Islands: in Larwood, G.P., and Nelson, C., eds., Recent and Fossil Bryozoa: Olsen and Olsen, Fredensborg, p. 101-103.

Gordon, D. P. 1984. The marine fauna of New Zealand: Bryozoa: Gymnolaemata from the Kermadec Ridge. New Zealand Oceanographic Institute Memoir 91:1-198.

Gordon, D. P. 1987, The deep-sea Bryozoa of the New Zealand region: in Ross, J.R.P., ed., Bryozoa: Present and Past: Western Washington University, Bellingham, p. 97-104. 
Gundrum, L. E. 1979. Demosponges as substrates: An example from the Pennsylvanian of North America. Lethaia 8:105-119.

Hageman, S. J., P. E. Bock, Y. Bone, and B. McGowran. 1998. Bryozoan growth habits: Classification and application. Journal of Paleontology 72:418-436.

Hageman, S. J., Y. Bone, B. McGowran, and N. P. James. 1996, Bryozoan species distribution on the cool-water Lacepede Shelf, southern Australia: in Gordon, D., Smith, A.M., and Mackey, J.G., eds., Bryozoans in Space and Time: National Institute of Water and Atmospheric Research Ltd., Wellington, p. 109-116.

Hayward, P. J. and P. L. Cook. 1979. The South African Museum's Meiring Naud cruises. Part 9. Bryozoa. Annals of the South African Museum 79:43-130.

Hayward, P. J. and P. L. Cook. 1983. The South African Museum's Meiring Naud cruises. Part 13. Bryozoa II. Annals of the South African Museum 91:1-161.

Hayward, P. J. and J. S. Ryl. 1991. Marine flora and fauna of the northeastern United States. NOAA Technical Report NMFS 99:1-48.

Henrich, R., M. Hartmann, J. Reitner, P. Schäfer, A. Freiwald, S. Steinmetz, P. Dietrich, and J. Thiede. 1992. Facies belts and communities of the Arctic Vesterisbanken Seamount (Central Greenland Sea). Facies 27:71-104.

James, N. P., Y. Bone, C. C. von der Borch, and V. A. Gostin. 1992. Modern carbonate and terrigenous clastic sediments on a cool-water, high energy, mid-latitude shelf; Lacepede Shelf, southern Australia. Sedimentology 34:877-904.

James, N. P., Y. Bone, S. J. Hageman, D. A. Feary, and V. A. Gostin. 1997, Cool-water carbonate sedimentation during the terminal quaternary, high-amplitude, sea level cycle: Lincoln Shelf, southern Australia: in James, N.P., and Clark, J.A., eds., Cool-Water Carbonates: SEPM Special Publication No. 56, p. 53-75.

James, N. P., T. D. Boreen, Y. Bone, and D. A. Feary. 1994. Holocene carbonate sedimentation on the Eucla Shelf, Great Australian Bight: A shaved shelf. Sedimentary Geology 90:161-177.

Jones, H. A. and P. J. Davies. 1983. Superficial sediments of the Tasmanian continental margin and part of Bass Strait. Bulletin of the Bureau of Mineral Resources 218:1-23.

Key Jr, M. M., W. B. Jeffries, H. V. Voris, and C. M. Yang. 1996, Epizoic bryozoans and mobile ephemeral host substrata: in Gordon, D., Smith, A.M., and Mackey, J.G., eds., Bryozoans in 
Space and Time: National Institute of Water and Atmospheric Research Ltd., Wellington, p. 157-165.

Land, L. S. 1970. Carbonate mud: Production by epibiont growth on Thalassia testudinum. Journal of Sedimentary Petrology 40:1361-1363.

Lenz, A. C. 1993. A Silurian sponge-inarticulate brachiopod life? association. Journal of Paleontology 67:138-139.

Lescinsky, H. L. 1997. Epibiont communities: Recruitment and competition on North American Carboniferous brachiopods. Journal of Paleontology 71:34-53.

Lukasik, J. J. and J. P. James. 1998. Lithostratigraphic revision and correlation of the OligoMiocene Murray Supergroup, western Murray Basin, South Australia. Australian Journal of Earth Science 45:889-902.

McKinney, F. K. and J. B. C. Jackson. 1989, Bryozoan Evolution: Unwin Hyman, Boston, 238 p.

Marshall, J. F. and P. J. Davies. 1978. Skeletal carbonate variation on the continental shelf of eastern Australia. B.M.R. Journal of Australian Geology and Geophysics 3:85-92.

Milliman, J. D., O. H. Pilkey, and D. A. Ross. 1972. Sediments of the continental margin off the eastern United States. Geological Society of America Bulletin 83:1315-1334.

Nelson, C. S., G. E. Hancock, and P. J. J. Kamp. 1981. Shelf to basin, temperate skeletal carbonate sediments, Three Kings Plateau, New Zealand. Journal of Sedimentary Petrology $52: 717-732$.

Nelson, C. S., S. L. Kean, and P. S. Head. 1988. Non-tropical carbonate deposits on the modern New Zealand shelf. Sedimentary Geology 60:71-94.

Nelson, J. E. and R. N. Ginsburg. 1986. Calcium carbonate production by epibionts on Thalassia in Florida Bay. Journal of Sedimentary Petrology 56:622-628.

Passlow, V. 1997, The derivation of mass transport sediments on the continental shelf of the Otway margin, southeastern Australia and the influence of shallow-water sediments: in James, N.P., and Clark, J.A., eds., Cool-Water Carbonates: SEPM Special Publication No. 56, p. 107125.

Patriquin, D. G. 1972. Carbonate mud production by epibionts on Thalassia: An estimate based on leaf growth rate data. Journal of Sedimentary Petrology 42:687-689. 
Pätzold, J., H. Ristedt, and G. Wefer. 1987. Rate of growth and longevity of large colony of Pentapora foliacea (Bryozoa) recorded in their oxygen isotope profiles. Marine Biology 96:535538.

Pestana, H. 1985. Carbonate sediment production by Sargassum epibionts. Journal of Sedimentary Petrology 55:184-186.

Rohr, D. M. and A. J. Boucot. 1989. Xenomorphism, bioimmuration, and biologic substrates: An example from the Cretaceous of Brazil. Lethaia 22:213-215.

Schäfer, P. 1994, Growth strategies of Arctic Bryozoa in the Nordic Sea: in Hayward, P.J., Ryland, J.S., and Taylor, P.D., eds., Biology and Paleobiology of Bryozoans: Olsen and Olsen, Fredensborg, p. 173-176.

Schopf, T. J. M. 1969. Paleoecology of ectoprocts (bryozoans). Journal of Paleontology 43:234244.

Smith, A. M. and C. S. Nelson. 1994. Calcification rates of rapidly colonising bryozoans in Hauraki Gulf, northern New Zealand. New Zealand Journal of Marine and Freshwater Research 28:227-234.

Smith, A. M. and C. S. Nelson. 1996, Differential abrasion of bryozoan skeletons: Taphonomic implications for paleoenvironmental interpretation: in Gordon, D., Smith, A.M., and Mackey, J.G., eds., Bryozoans in Space and Time: National Institute of Water and Atmospheric Research Ltd., Wellington, p. 305-313.

Stach, L. W. 1936. Correlation of zoarial form with habitat. Journal of Geology 44:60-65. CrossRef

Stebbing, A. R. D. 1971. The epizoic fauna of Flustra foliacea (Bryozoa). Journal of the Marine Biological Association of the United Kingdom 51:283-300.

Taylor, P. D. 1990. Preservation of soft-bodied and other organisms by bioimmuration-a review. Palaeontology 33:1-17.

Taylor, P. D. 1993, Bryozoa: in Benton, M.J., ed., The Fossil Record 2: Chapman and Hall, London, p. 465-489.

Taylor, P. D. 1994. Evolutionary palaeoecology of symbioses between bryozoans and hermit crabs. Historical Biology 9:157-205. 
Voigt, E. 1973, Environmental conditions of bryozoan ecology of the hardground biotope of the Maastrichtian Tuff-Chalk, near Maastricht (Netherlands): in Larwood, G.P., ed., Living and Fossil Bryozoa: Academic Press, London, p. 185-197.

Voigt, E. 1979, The preservation of slightly or non-calcified fossil Bryozoa (Ctenostomata and Cheilostomata) by bioimmuration: in Larwood, G.P., and Abbott, M.B., eds., Advances in Bryozoology [Systematics Association Special Volume No. 13]: Academic Press, London, p. 541-564.

Voigt, E. 1981, Upper Cretaceous bryozoan-seagrass association in the Maastrichtian of the Netherlands, in Recent and Fossil Bryozoa: in Larwood, G.P., and Nelson, C., eds., Recent and Fossil Bryozoa: Olsen and Olsen, Fredensborg, p. 281-298.

Wahl, M. 1989. Marine epibiosis. I. Fouling and antifouling: Some basic aspects. Marine Ecology Progress Series 58:175-189.

Wass, R. E., J. R. Conolly, and R. J. Maclntyre. 1970. Bryozoan carbonate sand continuous along southern Australia. Marine Geology 9:63-73.

White, M. G. 1984, Marine benthos: in Laws, R., ed., Antarctic ecology, v. 2: Academic Press, London, p. 421-461.

Winston, J. E. and P. J. Hayward. 1994, Bryozoa of the US Antarctic research program:

Preliminary report: in Hayward, P.J., Ryland, J.S., and Taylor, P.D., eds., Biology and Paleobiology of Bryozoans: Olsen and Olsen, Fredensborg, p. 205-210.

Ziegler, B. 1964. Bewuchs auf spongien. Paläontologische Zeitschrift 38:88-97. 
FIGURES \& TABLES

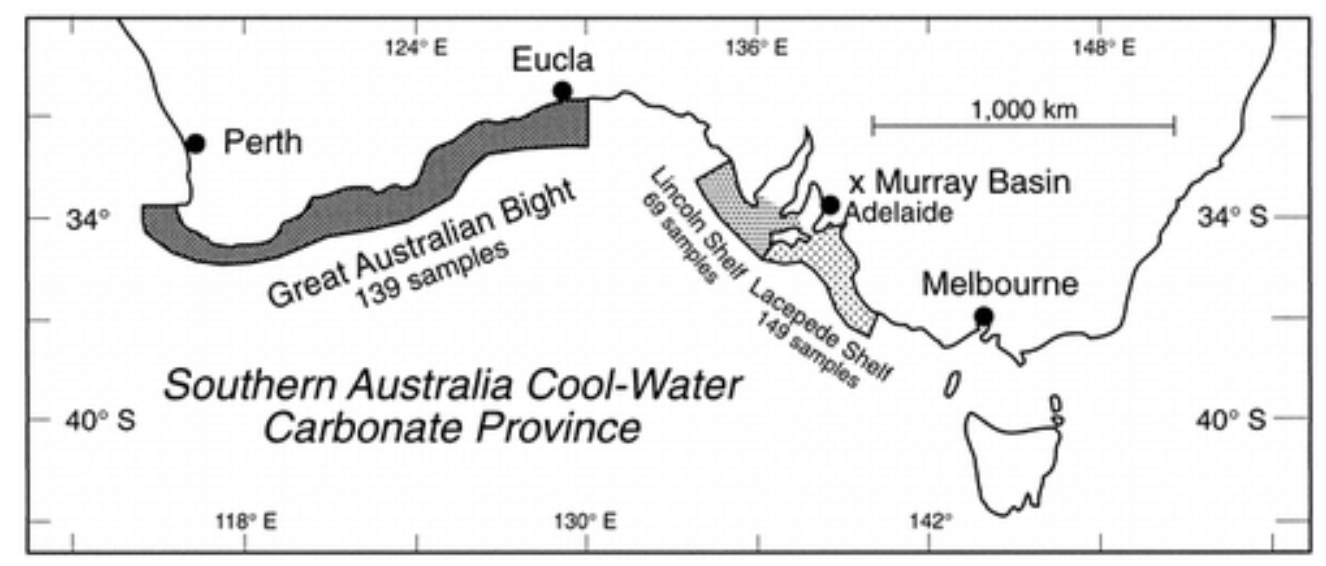

FIGURE 1-Southern Australian cool-water carbonate province and location of R.V. Franklin voyages (Lacepede Shelf, 1989 \& 1991; Lincoln Shelf 1994; Great Australian Bight 1995). Coolwater carbonate sediments (skeletal sands) are produced on the shelf over the entire region illustrated

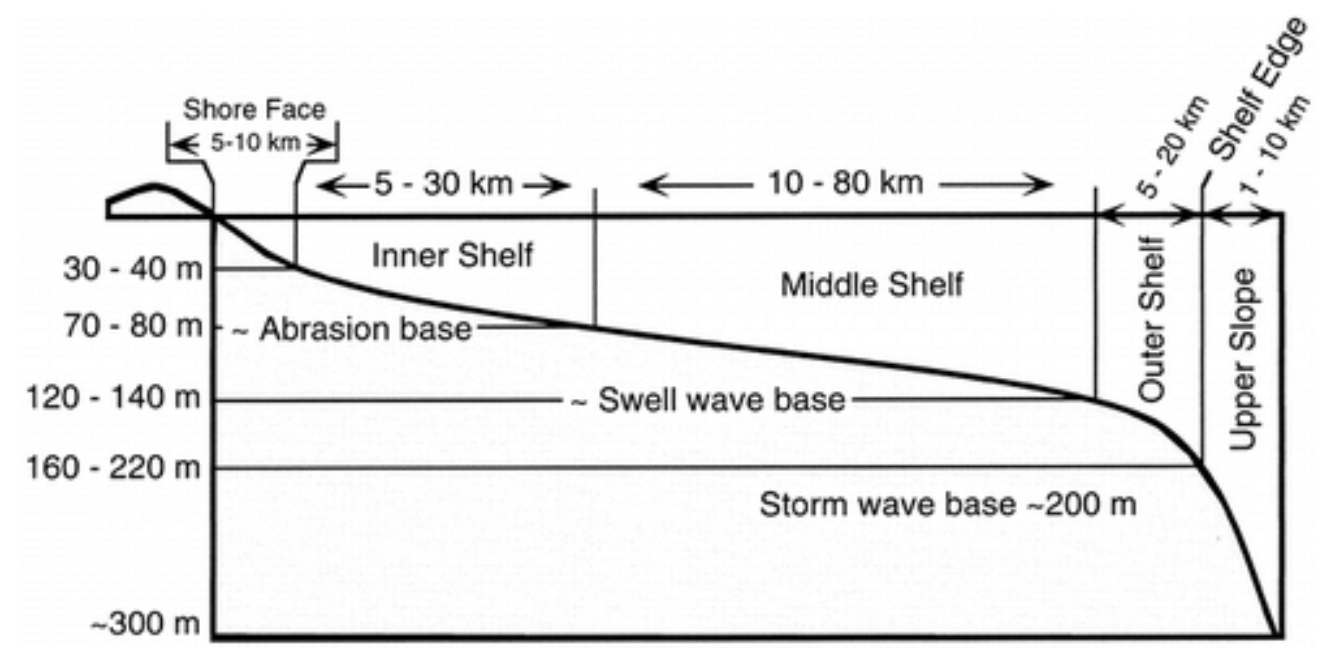

FIGURE 2-Idealized shelf profile across the southern Australian cool-water carbonate province. Consensus after James et al., 1992 (Lacepede Shelf); Boreen and James, 1993 (Otway Shelf); James et al., 1994 (Eucla Platform); James et al., 1997 (Lincoln Shelf); and unpublished data (Great Australian Bight). Vertical exaggeration $\times 125$. See Table 1 for characterization of regions 


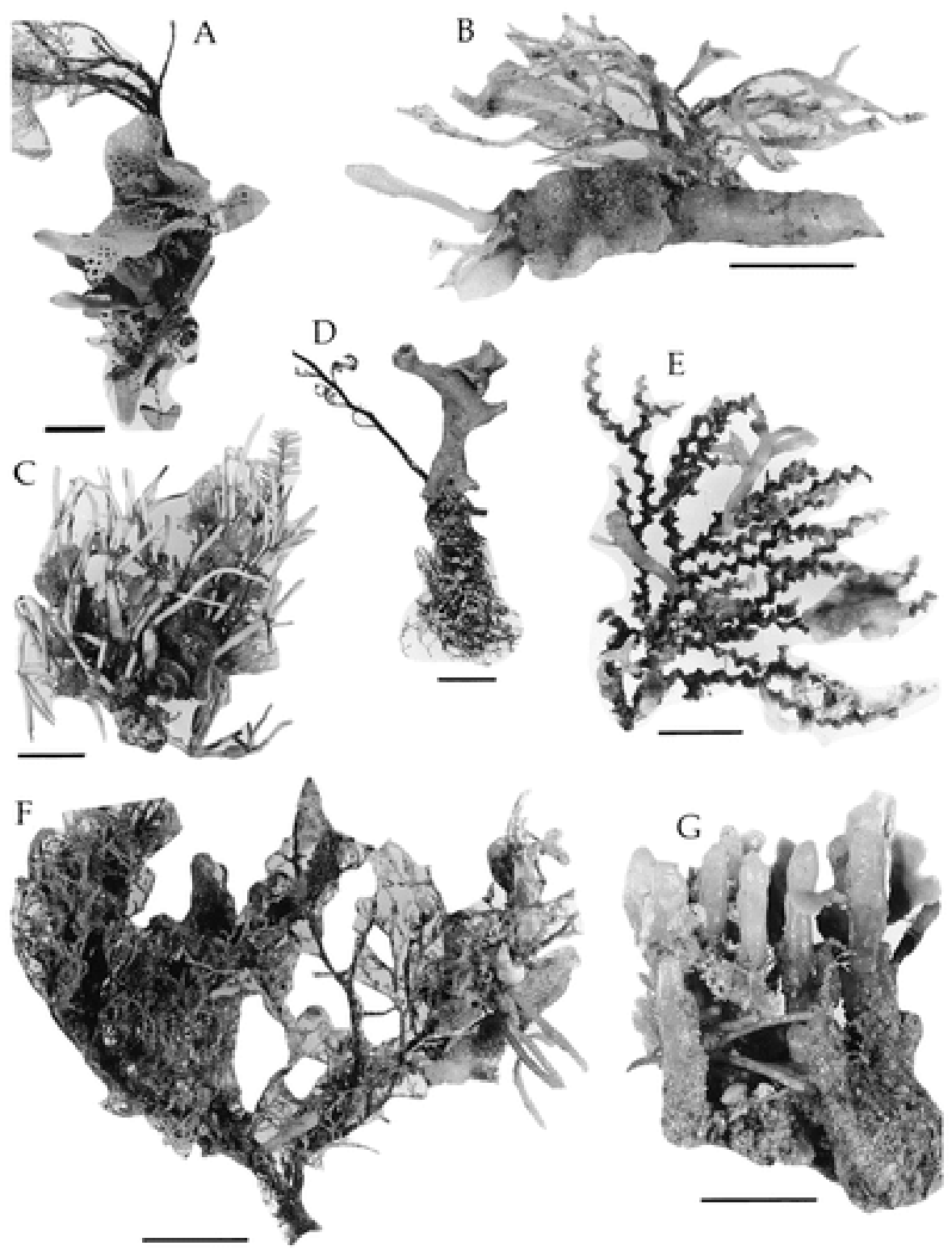

FIGURE 3-Epiathroic associations, all scale bars $=1 \mathrm{~cm}$. (A) Epizoans on cuticular roots of articulated zooidal bryozoan; PL94-25, 90 m (SAM L748). (B) Epizoans on exterior of soft worm tube, GAB-110, 154 m (SAM L749). (C) Epiphytes on exterior of Metagoniolithon, articulated calcareous red algae, Ward Island, $15 \mathrm{~m}$ (SAM L750). (D) Epizoan surrounding hydroid stem, with stabilizing roots, GAB-110, $154 \mathrm{~m}$ (SAM L751). (E) Epizoans on ctenostome soft bryozoan, Amathia sp., GAB-117, $65 \mathrm{~m}$ (SAM L752). (F) Diverse and abundant epizoans on a catenicellid, articulated zooidal bryozoan, GAB-117, 65 m (SAM L753). (G) Epizoans on exterior of digitate sponge, GAB-117, 65 m (SAM L754) 


\section{Occurrence of Bryozoan Growth Habit Characteristics in Epizoans}

\author{
Orientation relative to substrate \\ Encrusting \\ Massive \\ Erect-continuous \\ - Pedunculate \\ $x$ Fungiform
}

\section{Attachment to substrate}

Cemented

Rooted

- Free-living, sedentary or tumbled

- Free-living, avicularia supported

- Endolithic

- Regenerated (erect)

\section{Construction}

Rigid contiguous

Articulated, indeterminate cuticular connections

Articulated, determinant cuticular joints

Flexible weakly-calcified

Uncalcified

\section{Arrangement of zooecial series \\ Uniserial \\ Biserial \\ Oligoserial (3 -12) \\ Macroserial nonmaculate \\ Macroserial maculate}

observed as an epizoan (blank)

- not observed as an epizoan

$x$ not known from southern Australian shelf

\author{
Arrangement of frontal surfaces \\ Unilaminate \\ Bilaminate \\ $x$ Trilaminate \\ Quadrate \\ Radial \\ Multilaminate \\ Shape of Structural units \\ Single zooecium \\ Cluster of 2-5 zooecia \\ Runner-Branch with flat surface \\ Runner-Branch with convex surface \\ Sheet \\ Lobe \\ Disc \\ Solid Cylinder \\ Hollow Cylinder \\ Solid Cone-Cap-Dome \\ - Hollow Cone-Cap-Dome \\ Spheroid to Ellipsoid \\ Nodule

\section{Connection of structural units} \\ No lateral connections \\ Fused structural units \\ Extrazooecial skeletal connections \\ Cuticular tubes connecting structural units \\ Stolonate connection of zooecial units \\ Calcified tubes connecting zooecial units
}

FIGURE 4-Growth-habit characteristics of Bryozoa (after Hageman et al., 1998; figs. $3,4)$. Character states not observed in any of the southern Australian epizoans are labeled with "-" 


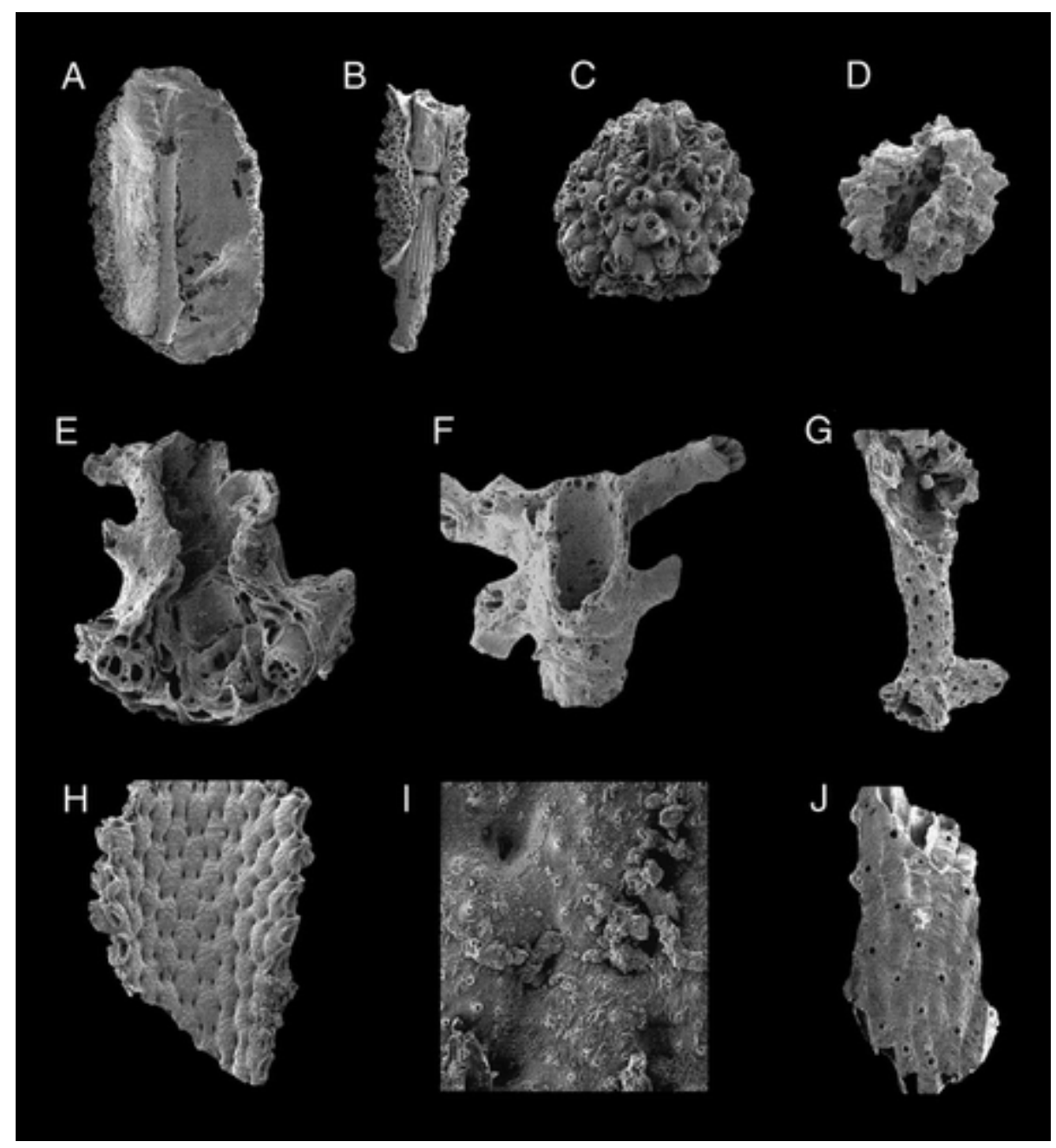

FIGURE 5-Skeletal morphology of basal attachment surfaces of probable epizoic bryozoans, Glenforslan Fm., Middle Miocene, Murray Basin, South Australia. Epibiontic characteristics for each specimen are summarized in Table 3. All specimens reposited in Appalachian State University collection. (A) Lichenoporid cyclostome Bryozoa encrusting a crisiid (articulated branching cyclostome bryozoan) host; ASU-5.1, ×8.5. (B) Lichenoporid cyclostome Bryozoa encrusting an articulated gorgonacean coral host; ASU-6.4, ×10. (C) Celleporinid Bryozoa encrusting a Cellaria (Bryozoa) host; ASU-5.3, x12.5. (D) Celleporinid Bryozoa encrusting an unidentified host; ASU-3.1, x12.5. (E) Reteporid bryozoan attached to another reteporid (ASU$4.3, \times 12.5)$. (F) Reteporid bryozoan attached to an unidentified psdeudoviniculariform ascophoran bryozoan. (ASU-8.1, ×10). (G) Smittoidea as a branching psdeudoviniculariform (ASU-6.2, ×8.5). $(\mathrm{H})$ Hiantiporid bryozoan, which was rooted to substrate by filaments trough holes (ASU-1.1, $\times 10$ ). (I) Hiantiporid bryozoan was rooted to its substrate by fine filaments through pores (ASU-1.3, $\times 50$ ). (J) Mucropetrealiellid bryozoan was rooted by filaments trough pores on the basal surface (ASU-6.1, ×10) 


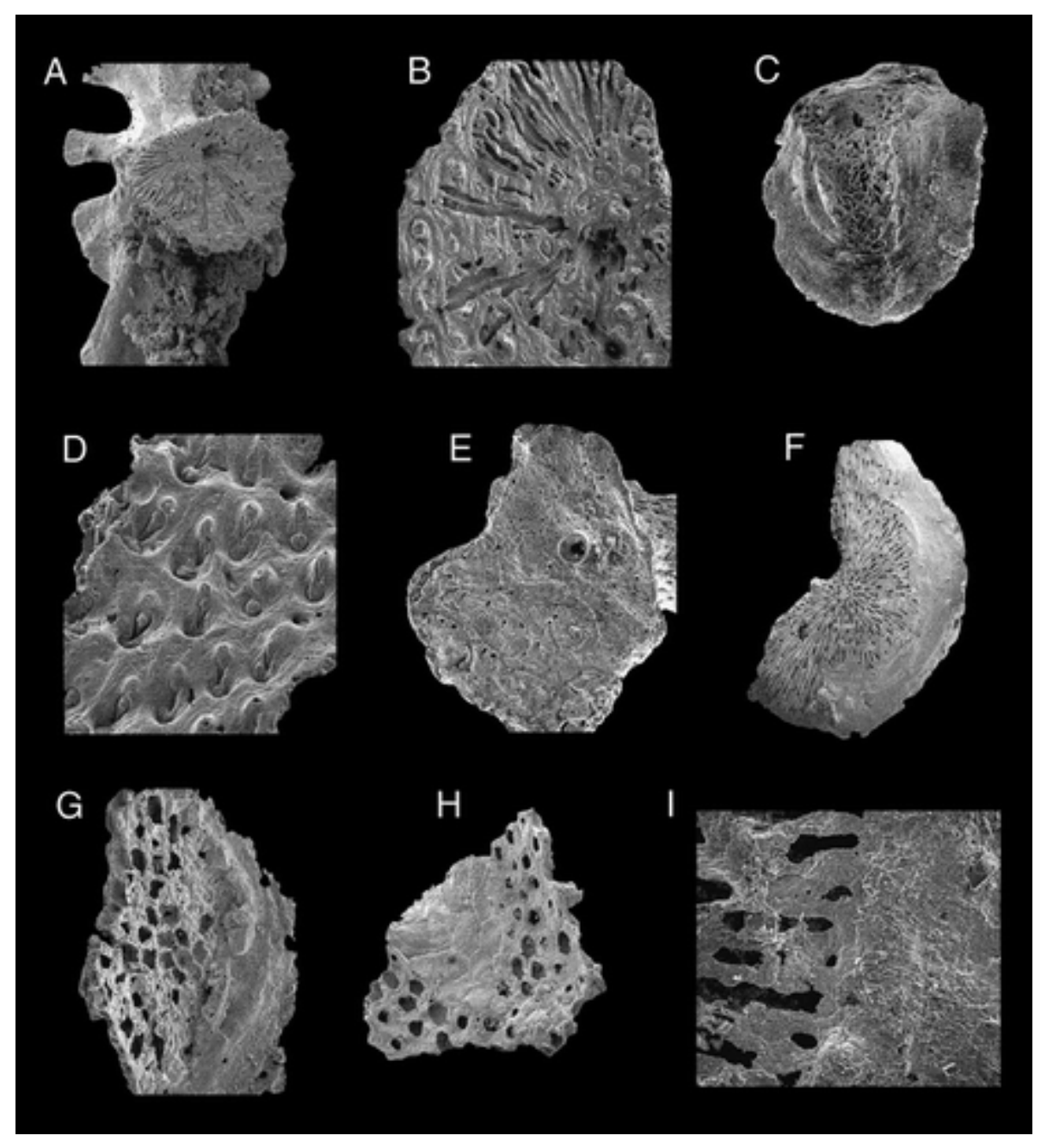

FIGURE 6-Skeletal morphology of basal attachment surfaces of probable epizoic bryozoans, Glenforslan Fm., Middle Miocene, Murray Basin, South Australia. Epibiontic characteristics for each specimen are summarized in Table 3. All specimens reposited in Appalachian State University collection. (A; B) unidentified erect cyclostome Bryozoa, with basal surface free from unidentified (bryozoan?) host; ASU-4.1, (A) $\times 12.5$, (B) $\times 30$. (C) Lichenoporid cyclostome Bryozoa, free from unidentified (branching bryozoan?) host; ASU-2.3, ×12.5. (D) Unidentified Bryozoa (retoporid cheilostome?), with bioimmured basal surface free from an unidentified host; ASU-8.3, $\times 30$. (E) Unidentified Bryozoa (hornerid cyclostome?), with basal surface free from an unidentified (bryozoan?) host; ASU-6.3, $\times 30$. (F, I) Lichenoporid cyclostome Bryozoa, free from unidentified host; ASU-2.1, (F) $\times 8.5$, (I) $\times 75$. (G) Unidentified ascophoran bryozoan, with basal surface free from an unidentified host; ASU-3.4, x12.5. (H) Unidentified ascrophoran bryozoan, with basal surface free from an unidentified branching host; ASU-5.2, ×10 

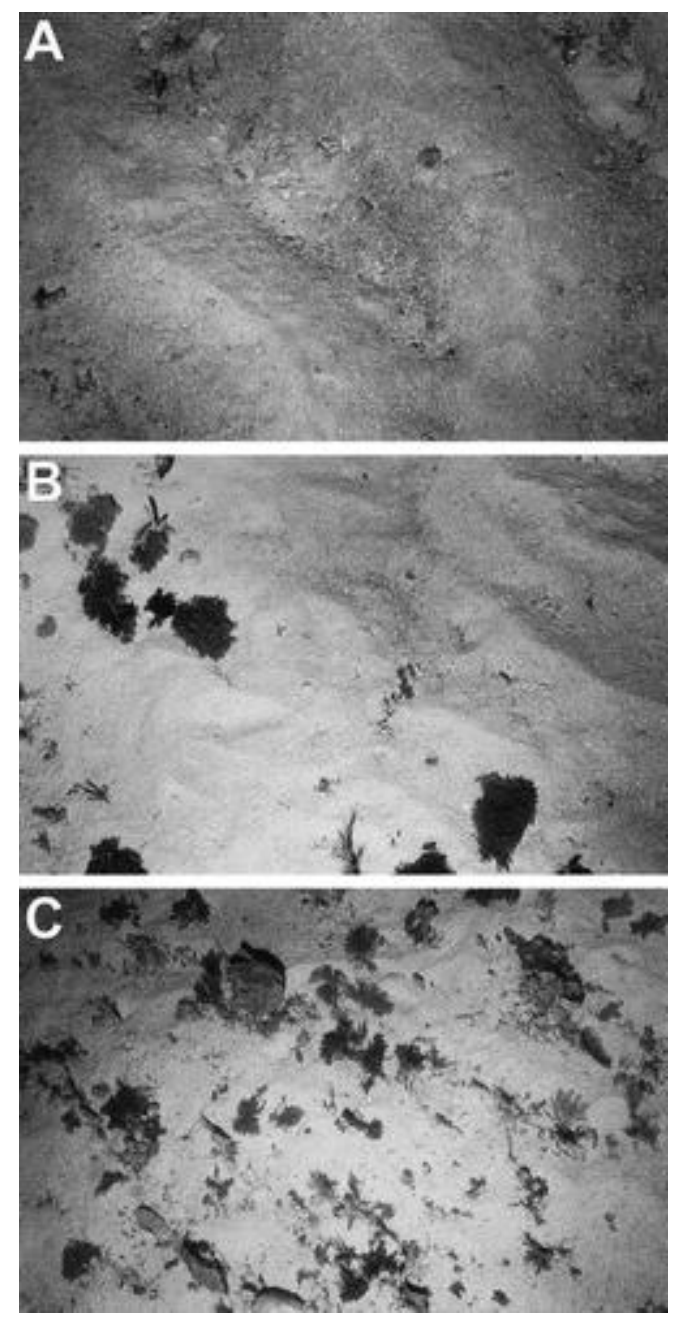

FIGURE 7-Underwater photographs of the Lacepede Inner Shelf, southern Australia; frame width $\approx 1.5 \mathrm{~m}$. (A) $120 \mathrm{~m}$ water depth, relatively barren zone of carbonate sand swept into dunes (Line 48). (B) $120 \mathrm{~m}$ water depth, development of epiathroic hosts (mostly catenicellid bryozoans) in a region of carbonate sand; note remnants of dunes in upper right (Line 48). (C) $100 \mathrm{~m}$ water depth, more complete development of epiathroic associations (catenicellid bryozoan and sponge hosts) in a region of carbonate sand, which has not been disturbed as recently as those in $A$ and $B$ (Line 53). Epizoans are not visible in underwater photographs produced by available equipment 


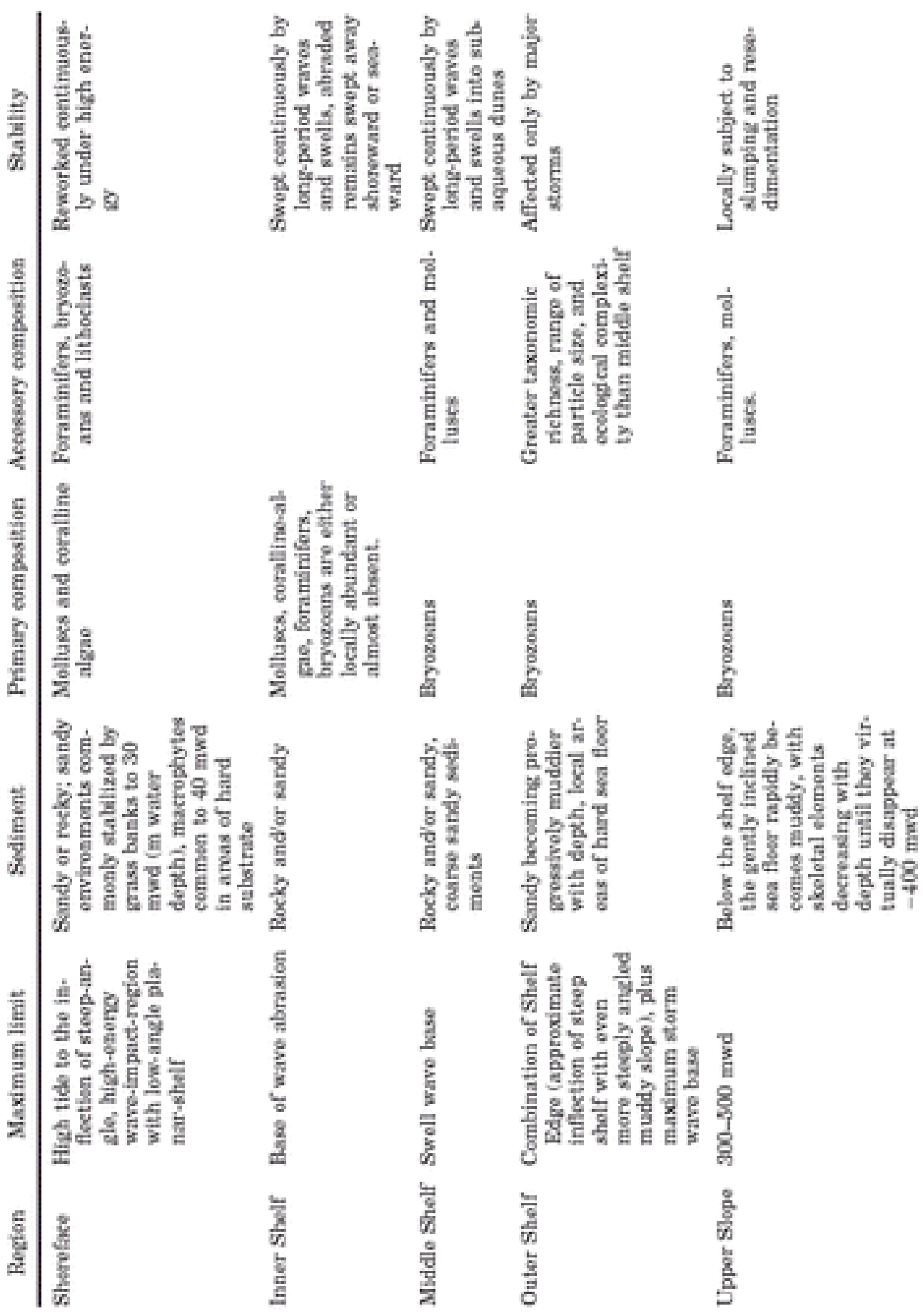

TABLE 1-Characterization of physiographic regions of the southern Australian shelf (see Fig. 2) 


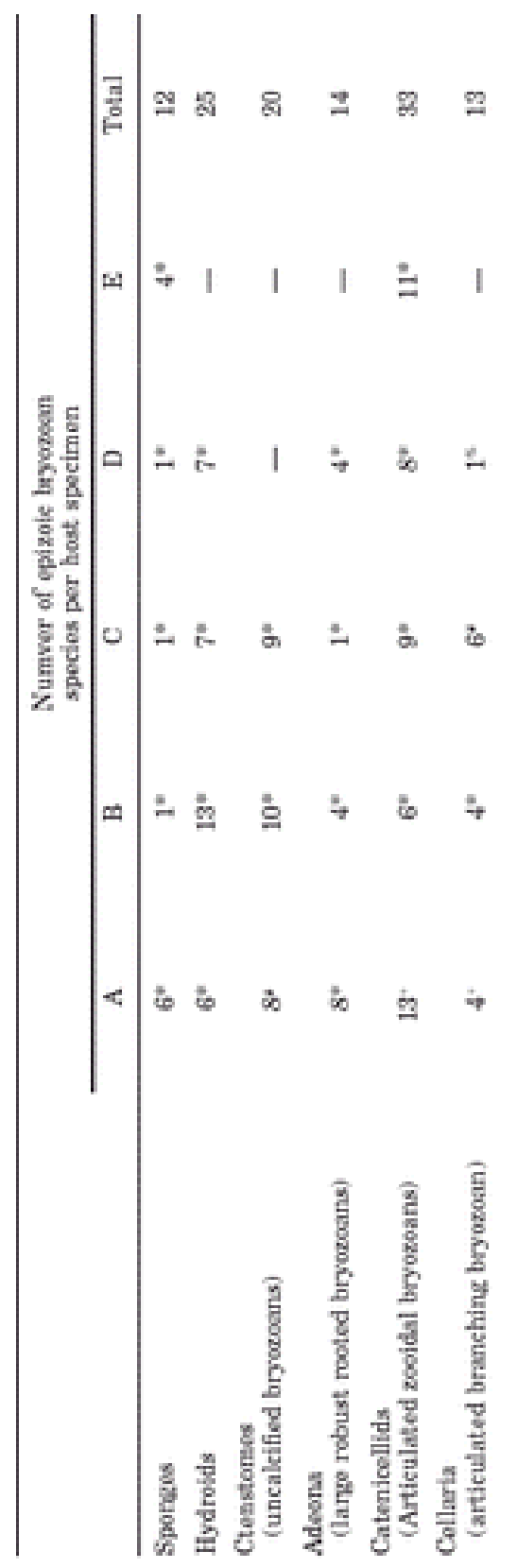

TABLE 2-The number of epizoic bryozoan species observed for each host is provided. Epiathroic associations studied from the Great Australian Bight of southern Australia (65-154 mwd) are grouped by host type. The total number of different epizoic bryozoan species observed on a given host type also is given. A total of 60 different epizoic bryozoan species were observed in this survey. Localities for host specimens are as follows: GAB128*; GAB117*; PL94-24*; GAB110*; GAB129\% 


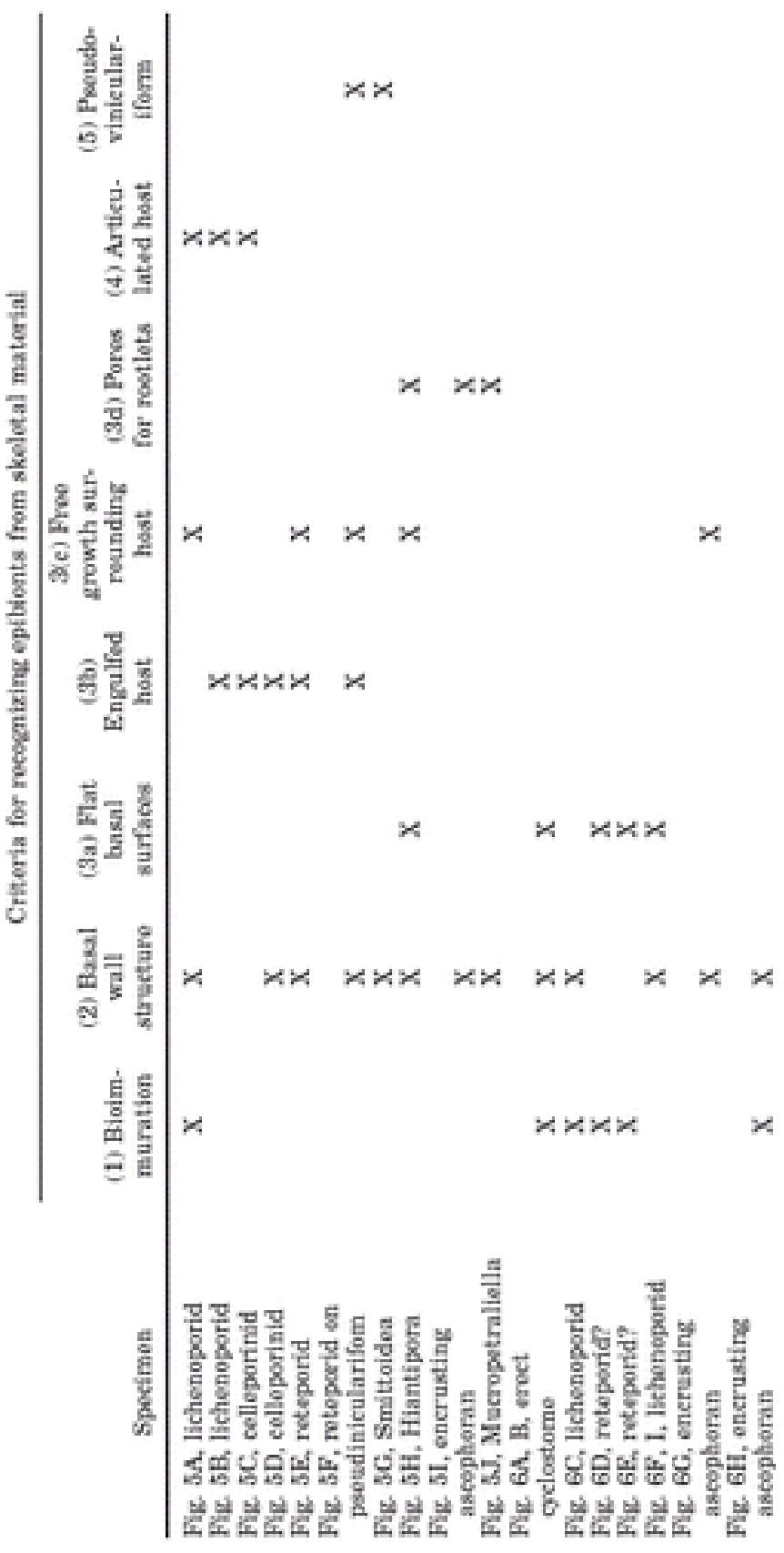

TABLE 3-Occurrences of epibiontic characteristics in specimens from Figures 5 and 6 


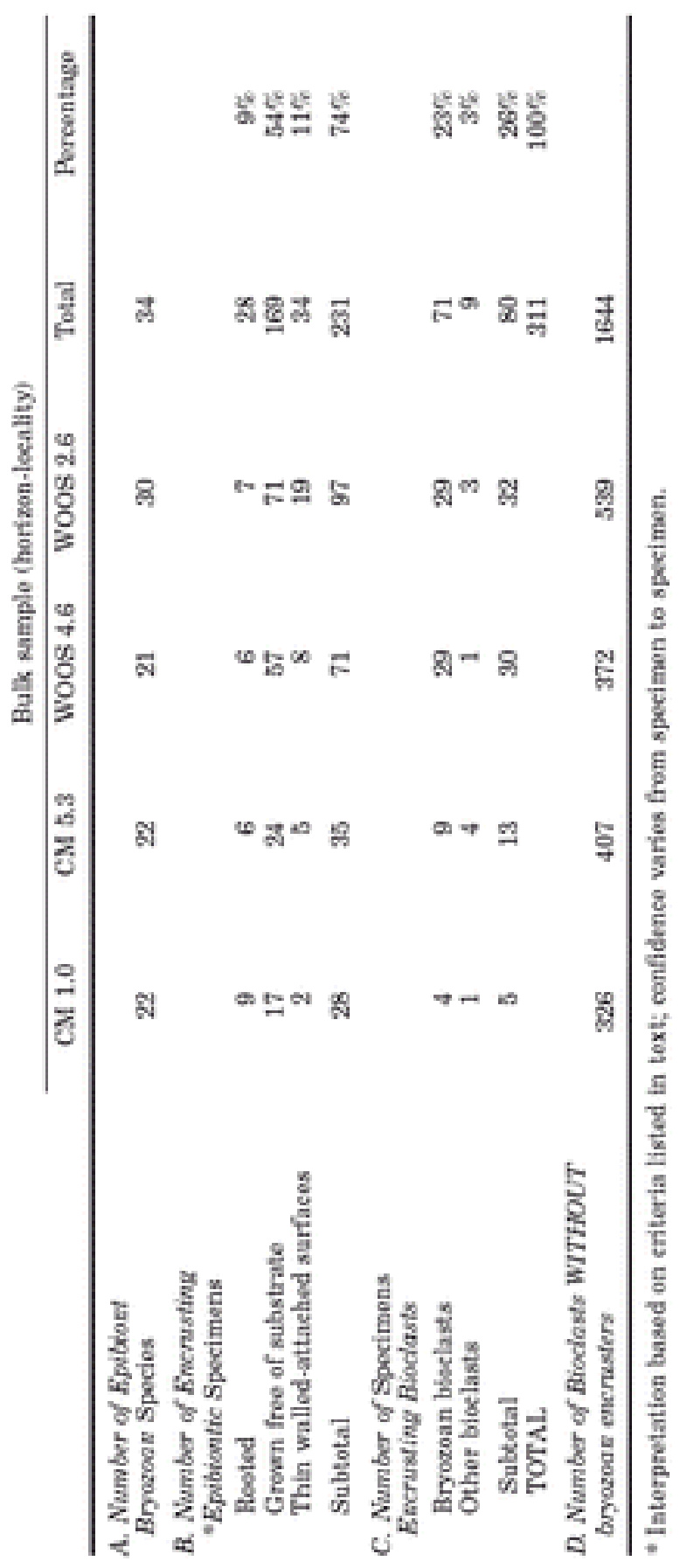

TABLE 4-Summary of substratal relationships of encrusting bryozoans from the Glenforslan Formation, Middle Miocene, South Australia 